\title{
アスファルトの低温脆性の評価に関する研究
}

\section{A RESEARCH ON LOW TEMPERATURE PROPERTIES OF ASPHALTS}

\author{
森吉昭博* - 藤原正浩** \\ By Akihiro MORIYOSHI and Masahiro FUJIWARA
}

\begin{abstract}
This paper describes the results of experimental research to the brittle properties of asphalts by means of Fraass breaking point test and new method measuring fracture temperatures of asphalts due to thermal stress at low temperatures (Moriyoshi Breaking Point Test). In this study, it is concluded that the brittle temperatures of asphalts (Moriyoshi Breaking Point) depend upon the refinery, the mixing plant, the date, the shape and thickness of vessel made of stainless steel and glass transition point of asphalt, and cracked shape of asphalt is closely related to the quality of asphalts.

Keywords : asphalt, brittle fracture, quality of asphalt
\end{abstract}

\section{1. まえがき}

アスファルト舖装の寒冷地における横断亀裂現象は約 50 年前に R.F. Rader ${ }^{1}$ に指摘され, その後多数の研究 者により解明しようと武みられてきた22)31. しかし, ア スファルトの低温領域における性状把握が不十分であっ たため, いまだにこの現象は防止することが難しいとさ れている.

この現象を抑えるために R. C. G. Haas ${ }^{4)}$ はアスファ ルトの限界のスティフネスを設定し, 横断龟裂の数を求 めるメモグラムを提案している. 菅原ら ${ }^{5}$ は熱応力破壊 試験の結果とアスファルトの限界のスティフネスから亀 裂温度を求めている.これらの方法はアスファルトの限 界のスティフネスをいずれもアスファルトの軟化点温度 や針入度から求めているため, 低温領域におけるアス ファルトの脆化温度を推定しているにすぎない. しかし 同一針入度級のアスファルトでもメーカーや製造法によ り低温性状が異なることが経験的にわかっている ${ }^{6)}$.し たがって直接アスファルトの低温性状をフラース脆化点

* 正会員 工博 北海道大学助教授 工学部土木工学科 ( (060 札幌市北区北 13 西 8)

** 学生会員 北海道大学大学院修士課程 工学部土木工学科 (現・JR 東日本 $($ 株))
試験から求めようとする方法もある7). しかし，この方 法はばらつきが多く, 実験の再現性に乏しいため, 研究 にはあまり利用されていない.

著者らはアスファルトの低温性状を簡単にかつ正確に 求める森吉脆化点試験を開発し（以下この試験から求め た脆化点を森吉脆化点とよぶ $)^{8)}$, この森吉脆化点が熱 応力破壊温度と密接な関係にあること年 11), また精度を 高めたフラース脆化点とも密接な関係にあることなどを 明らかにしている.

本研究は種々のアスファルトについて森吉脆化点試験 を実施し, 各アスファルトの低温脆性の評価およびこの 試験法の精度等について検討した結果について報告す る.

\section{2. 使用材料}

本研究で使用した主なアスファルト（ストレートアス 表一1＼cjkstart使用アスファルトのタイプおよび針入度級

\begin{tabular}{|c|c|c|c|c|c|c|}
\hline 針人度极 & \multicolumn{6}{|c|}{ アスファルトのタイブ } \\
\hline $80 / 100$ & Type A ${ }^{\circ}$ & Type B * & TypeC ${ }^{*}$ & Type D * & Tуре E $\sim 0 \cdots$ & Type $P, Q^{*}$ \\
\hline $100 / 150$ & Type A & & & & & \\
\hline $150 / 200$ & Type A & & & & & \\
\hline $180 / 200$ & & Type B & & & & \\
\hline
\end{tabular}

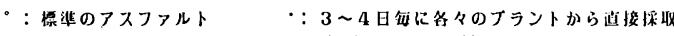

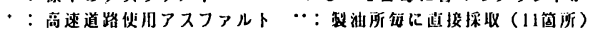


表一2 熱応力試験に使用したアスファルトの性状

\begin{tabular}{|c|c|c|c|c|c|c|c|c|}
\hline & $\begin{array}{l}\text { 針入度 } \\
\left(25^{\circ} \mathrm{C},\right. \\
100 \mathrm{~g}, \\
5 \mathrm{sec})\end{array}$ & $\begin{array}{c}\text { 饮化点 } \\
\text { ( } \mathrm{C} \text { ) }\end{array}$ & $\begin{array}{l}\text { 针人度 } \\
\text { 指数 }\end{array}$ & $\begin{array}{c}7 \overline{-} x \\
\text { 脆化点 } \\
(\mathcal{C})\end{array}$ & $\begin{array}{l}\text { 森吉 } \\
\text { 䴗化点 } \\
\left({ }^{\circ} \mathrm{C}\right)\end{array}$ & $\begin{array}{l}\text { 熱応力 } \\
\text { 破俵 } \\
\text { 温度 } \\
\left({ }^{\circ} \mathrm{C}\right)\end{array}$ & & \\
\hline 14 & 34 & 54.0 & $\cdot 1.1$ & -4 & -10 & $-19.0^{\circ}$ & & \\
\hline 15 & 44 & 60.5 & +0.8 & -12 & -23 & -29.0 & & \\
\hline 16 & 60 & 50.0 & -0.6 & -10 & -21 & -27.9 & & \\
\hline 17 & 69 & 50.5 & -0.2 & -12 & -22 & -28.5 & & \\
\hline 18 & 108 & 44.5 & -0.7 & -14 & -25 & -33.0 & & \\
\hline 19 & 173 & 40.5 & -0.4 & -21 & .30 & -36.4 & $-39.4 \%$ & \\
\hline 20 & 235 & 37.5 & -0.4 & -21 & -32 & -38.4 & & \\
\hline 10 & 90 & 47.5 & -0.4 & -13 & .24 & -31.0 & $\cdot 30.5$ & $-33.6 \cdots$ \\
\hline 8 & 98 & 44.0 & -1.2 & -12 & -19 & -29.0 & -28.8 & -27.5 \\
\hline 11 & 109 & 47.6 & +0.3 & -19 & -28 & -35.4 & -36.6 & -36.9 \\
\hline 9 & 69 & 52.0 & +0.1 & -10 & -18 & -28.1 & -27.9 & -27.1 \\
\hline 12 & 85 & 47.5 & & -15 & -27 & & & -34.5 \\
\hline 13 & 90 & 46.5 & & .15 & -24 & & & -29.9 \\
\hline
\end{tabular}

*：洽却速度 $-12^{\mathrm{c}} \mathrm{C} / \mathrm{h}$ 、突合せ治具

**: 冷却速度 -12 C $/ \mathrm{h}$ 、袋状治具

$* * *$ ：椧却速度 $-30 \tau / \mathrm{h}$ 、袋状治具

ファルト) は表一1に示すとおりである. なお, 熱応力 試験およびこれとの対応をみるために行ったフラース脆 化点試験および森吉脆化点試験に使用したアスファルト は表一2に示す。このときの混合物は密粒度アスファル トコンクリート（アスファルト量 $5.8 \%$, 最大粒径 13 $\mathrm{mm}$ )を用いた。

\section{3. 実験方法}

\section{（1）森吉脆化点試験}

アスファルトを直径 $14 \mathrm{~cm}$, 深さ $1 \mathrm{~cm}$, 厚さ $1 \mathrm{~mm} の$ ステンレス製の皿の容器 2 個におのおの $50 \mathrm{~g}(0.49 \mathrm{~N}$, 皿上で厚さ $3 \mathrm{~mm}$ となる) ずつ取り, 約 $120^{\circ} \mathrm{C}$ まで加熱 融解し, その後徐冷し両試料を $45^{\circ} \mathrm{C}$ の恒温室内に 10 分間以上保管し, 1 個の試料を一定温度のメタノールの 低温水槽内に 1 分間投入し, その後すぐ取り出してアス ファルトに亀裂があるかどうかを目で確認する。亀裂が あれば別の試料を用いて同温度で同様の作業を行うが, 亀裂がない場合は再度恒温室内で試料を 10 分間以上保 管し，試料を交互に用いてさらに $1^{\circ} \mathrm{C}$ 低い温度で同様 の作業を繰り返す. 両試料の破壊温度差が $3^{\circ} \mathrm{C}$ 以上あ れば実験はやりなおす．この試験の森吉脆化点は両試料 のうち高い方の温度とし, 亀裂の形状の検討に際しても その方を採用する ${ }^{12)}$.

脆化点において生じたアスファルトの亀裂の形状は大

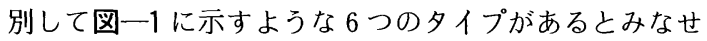
る. まずタイプIは亀裂が皿の端部から端部へと連続的 に入る場合であり, タイプII は亀裂が端部から出発して, 途中で止まっている場合である. さらに図一1に示すよ うに多数の亀裂の入るタイプIIIの亀裂や中央部にのみ亀 裂がみられる夕イプIの亀裂がある.また，このほかに 特異な例として亀裂が直線的でなく, 網の目状に入る夕 イプVの亀裂，および図一1のように皿の端部に沿って 円周状に入る夕イプVの亀裂がある ${ }^{13)}$.
I

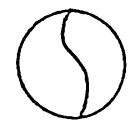

IV

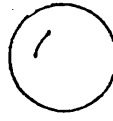

Ш

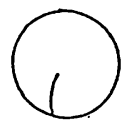

III

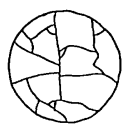

$\mathrm{V}$

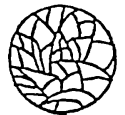

VII

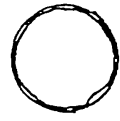

図一1㫣裂の形状のタイプ分け

以上は標準の実験であるが, 本研究では比較・検討の ため以下のような特殊な条件でも実験を行った。なお, その設定以外は標準の条件と同様に行った.

(1) 水槽温度を $0.2^{\circ} \mathrm{C} こ ゙ と に$ 変化させたもの

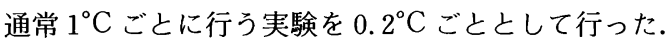
なお，皿は 6 枚用意してこれらを循環的に使用すること とした.

(2) アスファルトの厚さを変化させたもの

皿上のアスファルトの厚さを標準の $3 \mathrm{~mm}$ のほか, $0.5 \mathrm{~mm}, 1 \mathrm{~mm}, 6 \mathrm{~mm}$ 厚でも行った.

(3) 皿の材質や寸法を変化させたもの

表一4に示すようなさまざまな皿について行った。

\section{（2）フラース脆化点試験}

DIN U 6 に準拠した方法で行ったが，装置本体を低 温水槽内のメタノール中に浸し, 冷却速度 $-1^{\circ} \mathrm{C} / \mathrm{min}$ のもとで 1 分ごとに本体を取り出してアスファルト試料 の亀裂の有無を確認し, 亀裂が初めて認められた温度を 脆化点温度とする方法をとった. このとき温度は温度精 度 $\pm 0.01^{\circ} \mathrm{C}$ のデジタル温度計で測定した。この方法で は従来の方法より著しく実験精度が改善されている ${ }^{14)}$.

\section{（3）熱応力破壊試験}

この試験は供試体寸法 $2.5 \times 2.5 \times 26 \mathrm{~cm}$ の棒状のア スファルト混合物を両端固定し, 周囲のメタノールの温 度を低温水槽とプログラム温度設定器を用いて $\pm 0.1^{\circ} \mathrm{C}$ の精度で温度制御しながら, ある温度から一定冷却速度 でアスファルト混合物が熱応力で破壊するまで実施す る.この装置は荷重および温度による荷重計や治具の変 形量をできるだけ少なくなるように配慮されている．荷 重の記録はデータロガと自動平衡型記録計を用い 2 分間 隔にデジタル入力と同時にアナログ入力も行った.

解析は荷重が最大となり，アスファルト混合物が破壊 するときの温度を熱応力破壊温度とし，熱応力は測定さ れた荷重を供試体の元の断面積で除したものとした。ま た, 熱応力破壊強度は破壊温度における熱応力とした ${ }^{15)}$.

\section{（4）実験水槽}

森吉脆化点試験, フラース脆化点試験および熱応力破 壊試験で使用した実験水槽は $0.1^{\circ} \mathrm{C}$ 単位の温度設定が 可能であり, 調節精度は土 $0.01^{\circ} \mathrm{C}$ である. 水槽内の温 度は設定温度のみに頼るのを避け, 別個に $\pm 0.01^{\circ} \mathrm{C}$ の 
デジタル温度計を用いて計測した。

\section{（5）ガラス転移点の測定}

高分子物質はある一定の温度でその物質特有の粘性を 失ってガラス状となり，その温度を境にして熱膨張係数 や比熱, および比容（1グラムの体積）の温度による変 化の程度が著しく異なる。これをガラス転移と称し，そ の温度をガラス転移点という。本研究ではプラントから ある日付けごとに採取したアスファルトの一部の試料に ついて,このガラス転移点を測定し，脆化点試験結果と の比較・検討を試みた. 測定は試料を約 $30 \mathrm{mg}$ とり, 高感度示差熱量計（DSC-10 A) によった。この試験装 置は酸化アルミニウムの粉末を基準物質とし，これと試 料の温度を等しく保ち両者の必要なエネルギーの差を測 定し, その計測結果から不連続となった点の温度からガ

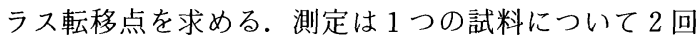
行った.

\section{4. 結果および考察}

\section{（1）森吉脆化点の精度について}

表一3 は通常 $1^{\circ} \mathrm{C} こ ゙ と に$ 水槽温度を低下させて行う実

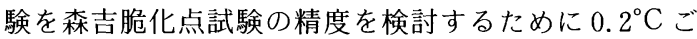
ととした場合の森吉脆化点と亀裂の形状の夕イプとを示 す.アスファルトは Type A の 80/100 であり，6枚の 四を循環的に使用した。この結果より，亀裂の初出した 温度の各血でのばらつきの程度を調べると最高でー $24.8^{\circ} \mathrm{C}$ ，最低で-25. $6^{\circ} \mathrm{C}$ であり，その範囲は $0.8^{\circ} \mathrm{C}$ で ある.したがって森吉脆化点試験での脆化点温度は測定 のための温度間隔は妥当なものといえよう。一方，亀裂 の形状を比較すると標準の実験では亀裂が相当多数入っ ているのに対し，この実験結果では比較的少なかった。 このことより，温度間隔を小さくすると本数の多い亀裂 は生じづらいものと考えられる.

\section{（2）血上のアスファルトの厚さによる違い}

表一4 はアスファルト (Type A の 80/100 使用) の厚 さが $0.5 \mathrm{~mm}, 1 \mathrm{~mm}, 3 \mathrm{~mm}, 6 \mathrm{~mm}$ の 3 つ場合で皿の 大きさ，数種の材質について実験を行った場合の森吉脆 化点を示す.これによると森吉脆化点の值は $1 \mathrm{~mm}$ よ 3 $\mathrm{mm}$ との間では大差ないが，厚さ $6 \mathrm{~mm}$ の方がおおよそ $1 \sim 2^{\circ} \mathrm{C}$ 低くなっている.これは厚さが $6 \mathrm{~mm}$ 程度とな ると熱の伝達が悪くなり，試料自体の温度が一様となる 時間が異なるためと考えられる，厚さ $6 \mathrm{~mm}$ の場合，実 験中に亀裂の生じたらしい音がその目で確認される温度 よりも $1 \sim 2{ }^{\circ} \mathrm{C}$ 高い温度で聞こえたこともあったほか, 亀裂確認よりも高い温度で，すでに皿の底部では亀裂の 生じているらしい表面での線状の盛り上がり現象が一部 のデータで確認されている，また，厚さ $1 \mathrm{~mm}$ 以下の場 合，亀裂の幅は他に比較して細く，確認は比較的困難で
表一3 $0.2^{\circ} \mathrm{C}$ ごとに行った森吉脆化点試験結果

\begin{tabular}{|l|c|c|c|c|c|c|}
\hline 四の番号 & 1 & 2 & 3 & 4 & 5 & 6 \\
\hline 森吉脆化点 ( $\left.{ }^{\circ} \mathrm{C}\right)$ & -24.8 & -24.8 & -25.4 & -25.4 & -25.2 & -25.6 \\
\hline 衰裂形状のタイフ & I & I & I & I & I & I \\
\hline
\end{tabular}

表一4＼cjkstart血の材質・大きさおよびアスファルト 厚を変化させた森吉脆化点試験結果

\begin{tabular}{|c|c|c|c|}
\hline 听の材犋 & $\begin{array}{r}\text { III の内径 } \\
(\mathrm{cm})\end{array}$ & $\begin{array}{r}3 \times 7>11+F \\
(\mathrm{~mm})\end{array}$ & $\begin{array}{c}\text { 森吉胞化战 } \\
\left.\text { ( }{ }^{\circ} \mathrm{C}\right)\end{array}$ \\
\hline \multirow{7}{*}{$\begin{array}{r}\text { ステン } \\
\text { レス }\end{array}$} & \multirow{4}{*}{14} & 0.5 & -26 \\
\hline & & 1 & -27 \\
\hline & & 3 & -26 \\
\hline & & 6 & -28 \\
\hline & \multirow{3}{*}{10} & 1 & -28 \\
\hline & & 3 & -28 \\
\hline & & 6 & -29 \\
\hline 同、溙無 & 14 & 1 & -27 \\
\hline \multirow{6}{*}{$\begin{array}{l}ア ル ミ \\
\text { ニウム }\end{array}$} & \multirow{3}{*}{14} & 1 & -28 \\
\hline & & 3 & -28 \\
\hline & & 6 & -30 \\
\hline & \multirow{3}{*}{12} & 1 & -28 \\
\hline & & 3 & -28 \\
\hline & & 6 & -34 \\
\hline \multirow{3}{*}{$\begin{array}{l}\text { インバ } \\
\text { ール・ }\end{array}$} & \multirow{3}{*}{14} & 1 & -29 \\
\hline & & 3 & -29 \\
\hline & & 6 & -29 \\
\hline 真ちゅう & 10 & 1 & -24 \\
\hline
\end{tabular}

あった。一方，厚さ $0.5 \mathrm{~mm}$ の場合も森吉脆化点はほぼ 同じであった。ただし，この場合は亀裂形状が他と大分 異なり，縁のない皿での場合と同様に中央部分のみと なった。これはアスファルトの厚さがこのように著しく 薄いことにより皿の端部の縁の影響がきわめて少なく なったためと思われる。

以上より, 厚さ $3 \mathrm{~mm}$ 程度が最も試験の遂行上妥当な 厚さであると考えられる.

\section{（3）皿の大きさ，形状，材質による違い}

表一4 はアスファルトがすべて同一 (Type Aの 80/100 使用）で大きさ，形状および材質の異なる 5 種 類の皿を用いて森吉脆化点武験を行った結果を示す.

これによると他の 3 種のものと比較してステンレス製 の内径 $14 \mathrm{~cm}$ の場合が亀裂の発生温度が比較的高く, 
インバール製のものが低くなっている．また，ステンレ ス製の皿では，大きい皿の方が亀裂の入る温度が若干高 くなっているとみることができる．これは皿の大きいほ ど同じ温度にさらされた場合，表面積が大きいため，受 ける影響も大きく，亀裂発生が容易になるためと思われ る. また，インバール製の血で森吉脆化点が低くなった のは材質ではなく，この皿の肉厚が厚く，熱容量が大き くなったことに起因するものと思われる，すなわち，皿 の熱容量が大きいため，同じ水槽温度の設定でもこの血 の場合は実際にアスファルトが冷媒と同じ温度に達する までにより時間を要しているためと考えられる，また， アルミ製の皿で森吉脆化点が低いのはステンレス製のも のよりも材質が軟らかく, 剛性が小さいためと思われる. なお，アルミ製の小型の方の皿では亀裂は端部にのみ入 り，確認は特に困難であった。これは皿の端部では特に 応力が集中することと無縁ではないと思われる ${ }^{16)}$.また， 縁のない皿では亀裂は皿の中央部のみに生じ，その形状 も細かい網の目状となり（前述のタイプIV，タイプVの 亀裂の複合したもの), 他の形状と著しく異なった。

以上より，使用したいずれの皿でも実験は可能である が，皿の形状によって森吉脆化点が若干異なる結果とな るため, 種々のアスファルトの性状を比較するには同一 形状で同一の材質の皿を用いなければならないことがわ かる.

（4）針入度級の異なるァスファルトを混合した場合

表一 5 に Type B の 80/100 と Type B の 180/200の アスファルトの割合を変えて混合した後, $120^{\circ} \mathrm{C} て ゙ 12$ 時間放置した場合のおのおのの森吉脆化点と亀裂の形状 を示した。これによると $80 / 100$ の森吉脆化点がー $24^{\circ} \mathrm{C}$, $180 / 200$ のそれがー $32^{\circ} \mathrm{C}$ であったのに対し，混合した 場合の森吉脆化点は割合に応じて両者の脆化点の中間の 值をとるのではなく，いずれも等しく180/200より 2 ${ }^{\circ} \mathrm{C}$ ほど高い温度であった。 また, 亀裂の形状は混合し ていない 2 者が前述のタイプIの亀裂に属するのに対し て，混合したものはタイプIIの亀裂に属している.

このことより亀裂がタイプII である場合，逆にそのア スファルトは異なったアスファルトを混合したものであ り，不均一なアスファルトであることが疑われ，また， 低温での性状も単に両者の割合に応じた中間的な値をと るとは限らないということができる.

また, 表一6にはメーカーが硬軟 2 種のアスファルト 表一5 針入度級の異なるァスファルトを混合した場合の森吉脆 化点

\begin{tabular}{|l|c|c|c|c|c|}
\hline $80 / 100 の$ 量：180/2000里 & $100: 0$ & $60: 40$ & $50: 50$ & $40: 60$ & $0: 100$ \\
\hline 森吉脃化点 ( $\left.{ }^{\circ} \mathrm{C}\right)$ & -24 & -30 & -30 & -30 & -32 \\
\hline 她裂形状のタイブ & 1 & II & II & II & 1 \\
\hline
\end{tabular}

\section{表一6 針入度級の異なるアスファルトでの試験結果}

\begin{tabular}{|l|c|c|c|}
\hline 針人度粐 & $80 / 100$ & $100 / 150$ & $150 / 200$ \\
\hline 森吉順化点 ( $\left.{ }^{\circ} \mathrm{C}\right)$ & -25 & -28 & -28 \\
\hline 裂形状のタイ丁 & $\mathrm{I}$ & $\mathrm{I}, \mathrm{II}$ & $\mathrm{n}$ \\
\hline
\end{tabular}

から中間の柔らかさのアスファルトを作成した 3 種の針 入度級のアスファルトにういての森吉脆化点試験の結果 と亀裂の形状を示した。これによると森吉脆化点は 100/150 と 150/200 の両アスファルトで変わらず，とも に 80/100 のアスファルトよりも $3^{\circ} \mathrm{C}$ ほざ低い温度と なった。また亀裂の形状をみると $80 / 100$ と $150 / 200$ と

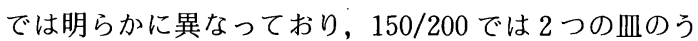
ち一方が 80/100, 他方が 150/200に近い形状となって いる.これより，100/150は80/100 と 150/200の両者 が混合されたことが亀裂形状からも確認できたように思 われる。

このようにアスファルトの亀裂形状がタイプII のよう になる原因は異種のアスファルトが混合されたとき得ら れたアスファルトのコロイド構造が不均一になるためと 思われる.このような現象は昔からいわれていたアス ファルトの不適合現象亡関係があると考えられる.

（5）森吉脆化点試験およびフラース脆化点試験から みた薄膜加熱試験前後の各社 (メーカーおよび 製油所）の性状の違いと日変動の比較

表一7，8，9 および図一2，3，4にプラントの異なる 3 社のメーカーの Type B D のアスファルトの脆化点 の日変動を薄膜加熱前, 後 $\left(163^{\circ} \mathrm{C}, 5 \mathrm{~h}\right)$ についてフラー 又脆化点試験, 森吉脆化点試験の両者について示す. ま た，表一10に製油所の異なる Type E〜O のアスファル トについての同様の試験結果を示す。いずれも針入度級 は同じ 80/100 である.

これより，まず両脆化点の試験結果を比較するとフ ラース脆化点は同じアスファルトについて 6 回試験を 行って $\pm 2 \sim 3^{\circ} \mathrm{C}$ 程度と試験值のばらつきが大きいのに 対して森吉脆化点は 2 回でいずれも $\pm 1^{\circ} \mathrm{C}$ の範囲におさ まっており, 後者の方がより精度の高い試験であるとい うことができる. 次に, 薄膜加熱前後で比較すると, 概 して薄膜加熱後のアスファルトは両脆化点はともに高い 傾向が認められる．これは薄膜加熱によりアスファルト の粘度や強度が変化するためと考えられる．したがって 加熱前後での脆化点温度の差はアスファルトによって異 なっている.

表一10 の製油所ごとのアスファルトの森吉脆化点は 製油所によってかなりのばらつきがみられる。これは同 じ針入度級とされていても製油所での生産段階からアス ファルトの性状はかなり異なることを示している. 
表一7 Type B のアスファルトでの脆化点試験結果 (プラント 1)

\begin{tabular}{|c|c|c|c|c|c|c|}
\hline \multirow{2}{*}{$\begin{array}{l}\text { 日 } \\
\text { 付 }\end{array}$} & \multirow{2}{*}{$\begin{array}{l}\text { 溥 } \\
\text { 膜 } \\
\text { 加 } \\
\text { 䓡 }\end{array}$} & \multicolumn{2}{|c|}{ フラース能化点試验 } & \multicolumn{3}{|c|}{ 吉脆化点圾驗 } \\
\hline & & $\begin{array}{l}\text { 脆化点 } \\
\left.\text { ( }{ }^{\circ} \mathrm{C}\right)\end{array}$ & $\begin{array}{c}\text { バラッキ } \\
\text { ( C) }\end{array}$ & $\begin{array}{c}\text { 脆化点 } \\
\left({ }^{\circ} \mathrm{C}\right)\end{array}$ & $\begin{array}{c}\text { バラッキ } \\
\left({ }^{\circ} \mathrm{C}\right)\end{array}$ & $\begin{array}{l}\text { 製饻の } \\
\text { 夕イフ }\end{array}$ \\
\hline \multirow[t]{2}{*}{$6 / 25$} & 前 & -15.5 & $-14 \sim-19$ & -23 & $-23 \cdot-25$ & II \\
\hline & 後 & -14.2 & $-13 \sim-19$ & -24 & なし & I, III \\
\hline \multirow[t]{2}{*}{$6 / 29$} & 前 & -15.2 & $-14 \sim-16$ & -24 & なし & IV \\
\hline & 後 & -14.4 & $-13 \sim-16$ & -21 & $-21 \cdot-22$ & II \\
\hline \multirow[t]{2}{*}{$7 / 1$} & 前 & -15.8 & $-14 \sim-19$ & -24 & $-24 \cdot-26$ & 1 \\
\hline & 後 & -14.3 & $-14 \sim-15$ & -24 & $-24 \cdot-25$ & 1 \\
\hline \multirow[t]{2}{*}{$7 / 3$} & 前 & -15.8 & $-15 \sim-18$ & -24 & なし & 1 \\
\hline & 後 & -13.5 & $-13 \sim-14$ & -22 & $-22 \cdot-24$ & 1 \\
\hline \multirow[t]{2}{*}{$7 / 6$} & 前 & -15.0 & $-14 \sim-16$ & -25 & なし & III \\
\hline & 後 & -14.5 & $-11 \sim-19$ & -24 & $-24 \cdot-25$ & II \\
\hline \multirow[t]{2}{*}{$7 / 9$} & 前 & -17.3 & $-16 \sim-20$ & -24 & $-24 \cdot-25$ & 1 \\
\hline & 後 & -15.3 & $-14 \sim-16$ & -23 & $-23 \cdot-24$ & II \\
\hline \multirow[t]{2}{*}{$7 / 12$} & 前 & -15.3 & $-14 \sim-17$ & -25 & $-25 \cdot-26$ & II \\
\hline & 後 & -14.8 & $-13 \sim-18$ & -22 & $-23 \cdot-23$ & U \\
\hline \multirow[t]{2}{*}{$7 / 15$} & 前 & -15.7 & $-15 \sim-16$ & -26 & $-26 \cdot-27$ & 11 \\
\hline & 後 & -14.5 & $-13 \sim-16$ & $\begin{array}{lll}-2 & 1\end{array}$ & $-21 \cdot-22$ & I \\
\hline \multirow[t]{2}{*}{$7 / 18$} & 前 & -15.2 & $-14 \sim-17$ & -25 & $-25 \cdot-26$ & II \\
\hline & 後 & -14.5 & $-13 \sim-16$ & -21 & $-21 \cdot-23$ & II \\
\hline \multirow[t]{2}{*}{$7 / 21$} & 前 & -14.2 & $-13 \sim-15$ & -25 & $-25 \cdots-26$ & I \\
\hline & 後 & -12.7 & $-11 \sim-14$ & -22 & $-22 \cdot-23$ & II \\
\hline \multirow[t]{2}{*}{$7 / 28$} & 前 & -14.2 & $-13 \sim-16$ & -26 & $-26 \cdot-27$ & II \\
\hline & 後 & -12.0 & $-11 \sim$ & -22 & なし & II, ИI \\
\hline
\end{tabular}

表一8 Type C のアスファルトでの脆化点試験結果 (プラント 2 )

\begin{tabular}{|c|c|c|c|c|c|c|}
\hline \multirow{2}{*}{$\begin{array}{l}\text { 日 } \\
\text { 付 }\end{array}$} & \multirow{2}{*}{ 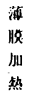 } & \multicolumn{2}{|c|}{ ララース胧化点战驗 } & \multicolumn{3}{|c|}{ 林吉能化点的验 } \\
\hline & & $\begin{array}{c}\text { 脆化点 } \\
\left({ }^{\circ} \mathrm{C}\right)\end{array}$ & $\begin{array}{c}\text { バラッキ } \\
\left.\text { ( }{ }^{\circ} \mathrm{C}\right)\end{array}$ & $\begin{array}{c}\text { 脆化点 } \\
\left({ }^{\circ} \mathrm{C}\right)\end{array}$ & $\begin{array}{c}\text { バラッキ } \\
\left({ }^{\circ} \mathrm{C}\right)\end{array}$ & $\begin{array}{l}\text { 危裂の } \\
\text { タイブ }\end{array}$ \\
\hline $7 / 2$ & $\begin{array}{l}\text { 瓶 } \\
\text { 後 }\end{array}$ & $\begin{array}{l}-114.2 \\
-13.2\end{array}$ & $\begin{array}{r}-9 \sim-15 \\
-12 \sim-15\end{array}$ & $\begin{array}{l}-25 \\
-25\end{array}$ & $\begin{array}{c}\text { なし } \\
-25 \cdot-26\end{array}$ & $\begin{array}{l}\text { II } \\
\text { IIII }\end{array}$ \\
\hline $7 / 6$ & $\begin{array}{l}\text { ini } \\
\text { 後 }\end{array}$ & $\begin{array}{l}-15.0 \\
-13.7\end{array}$ & $\begin{array}{l}-14 \sim-16 \\
-13 \sim-14\end{array}$ & $\begin{array}{l}-26 \\
-27\end{array}$ & $\begin{array}{c}-26 \cdots-28 \\
\text { なし }\end{array}$ & $\begin{array}{l}\text { IV } \\
\text { l }\end{array}$ \\
\hline $7 / 8$ & $\begin{array}{l}\text { iifi } \\
\text { 後 }\end{array}$ & $\begin{array}{l}-16.3 \\
-14.3\end{array}$ & $\begin{array}{l}-16 \sim \\
-14 \sim-15\end{array}$ & $\begin{array}{l}-27 \\
-26\end{array}$ & $\begin{array}{l}-27 \cdot-28 \\
-26 \cdot-27\end{array}$ & $\begin{array}{l}\text { II } \\
\text { l }\end{array}$ \\
\hline $7 / 9$ & 苚 & $\begin{array}{l}-15.0 \\
-15.3\end{array}$ & $\begin{array}{l}-14 \sim \\
-11 \sim-19\end{array}$ & $\begin{array}{l}-28 \\
-27\end{array}$ & $\begin{array}{l}\text { tic } \\
\text { tic }\end{array}$ & $\begin{array}{l}\text { II } \\
\text { I }\end{array}$ \\
\hline $7 / 11$ & $\begin{array}{l}\text { 而话 } \\
\text { 後 }\end{array}$ & $\begin{array}{l}-18.5 \\
-16.0\end{array}$ & $\begin{array}{l}-18 \sim \\
-14 \sim\end{array}$ & $\begin{array}{l}-27 \\
-27\end{array}$ & $\begin{array}{c}-27 \cdot-28 \\
\text { なし }\end{array}$ & $\begin{array}{l}\text { II } \\
\text { II }\end{array}$ \\
\hline $7 / 13$ & $\begin{array}{l}\text { 前 } \\
\text { 後 }\end{array}$ & $\begin{array}{l}-15.2 \\
-15.0\end{array}$ & $\begin{array}{l}-11 \sim-17 \\
-13 \sim-17\end{array}$ & $\begin{array}{l}-27 \\
-25\end{array}$ & $\begin{array}{c}\text { なし } \\
-25 \cdots-26\end{array}$ & $\begin{array}{l}\text { II } \\
\text { I }\end{array}$ \\
\hline $7 / 16$ & $\begin{array}{l}\text { 前 } \\
\text { 後 }\end{array}$ & $\begin{array}{l}-14.5 \\
-14.2\end{array}$ & $\begin{array}{r}-8 \sim-18 \\
-13 \sim-18\end{array}$ & $\begin{array}{l}-27 \\
-27\end{array}$ & $\begin{array}{l}\text { なし } \\
\text { なし }\end{array}$ & $\begin{array}{l}\text { II } \\
\text { I }\end{array}$ \\
\hline $7 / 18$ & $\begin{array}{l}\text { 前 } \\
\text { 後 }\end{array}$ & $\begin{array}{l}-15.2 \\
-14.5\end{array}$ & $\begin{array}{l}-14 \sim-17 \\
-13 \sim-15\end{array}$ & $\begin{array}{l}-26 \\
-25\end{array}$ & $\begin{array}{l}-26 \cdot-28 \\
-25 \cdot-27\end{array}$ & $\begin{array}{l}\text { II } \\
1\end{array}$ \\
\hline $7 / 22$ & $\begin{array}{l}\text { 前 } \\
\text { 後 }\end{array}$ & $\begin{array}{l}-16.2 \\
-15.3\end{array}$ & $\begin{array}{l}-15 \sim-18 \\
-14 \sim-17\end{array}$ & $\begin{array}{l}-25 \\
-24\end{array}$ & $\begin{array}{l}-25 \cdots-26 \\
-24 \cdot-26\end{array}$ & $\begin{array}{l}\text { II } \\
\text { I }\end{array}$ \\
\hline $7 / 24$ & $\begin{array}{l}\text { 前 } \\
\text { 後 }\end{array}$ & $\begin{array}{l}-15.0 \\
-15.3\end{array}$ & $\begin{array}{l}-14 \sim-17 \\
-13 \sim-20\end{array}$ & $\begin{array}{l}-27 \\
-25\end{array}$ & $\begin{array}{l}-27 \cdots-28 \\
-25 \cdots-26\end{array}$ & $\begin{array}{l}\text { III } \\
\text { II }\end{array}$ \\
\hline $7 / 27$ & $\begin{array}{l}\text { 前 } \\
\text { 後 }\end{array}$ & $\begin{array}{l}-16.8 \\
-14.2\end{array}$ & $\begin{array}{l}-13 \sim-18 \\
-13 \sim-15\end{array}$ & $\begin{array}{l}-26 \\
-25\end{array}$ & $\begin{array}{c}\text { なし } \\
-25 \cdots-27\end{array}$ & $\begin{array}{l}\text { II } \\
\text { I }\end{array}$ \\
\hline $7 / 29$ & $\begin{array}{l}\text { iiji } \\
\text { 後 }\end{array}$ & $\begin{array}{l}-15.5 \\
-15.8\end{array}$ & $\begin{array}{l}-14 \sim-17 \\
-15 \sim\end{array}$ & $\begin{array}{l}-25 \\
-26\end{array}$ & $\begin{array}{c}-26 \cdot-27 \\
\text { なし }\end{array}$ & $\begin{array}{l}1 \\
\text { II }\end{array}$ \\
\hline
\end{tabular}

表一9 Type Dのアスファルトでの脆化点試験結果 (プラント 3 )

\begin{tabular}{|c|c|c|c|c|c|c|}
\hline \multirow{2}{*}{$\begin{array}{l}\text { 日 } \\
\text { 付 }\end{array}$} & \multirow{2}{*}{$\begin{array}{l}\text { 薄 } \\
\text { 膜 } \\
\text { 加 } \\
\text { 熟 }\end{array}$} & \multicolumn{2}{|c|}{ Jラー2脆化点封验 } & \multicolumn{3}{|c|}{ 森吉脆化点却奘 } \\
\hline & & $\begin{array}{l}\text { 脆化点 } \\
\left({ }^{\circ} \mathrm{C}\right)\end{array}$ & $\begin{array}{c}\text { バラッキ } \\
\left({ }^{\circ} \mathrm{C}\right)\end{array}$ & $\begin{array}{l}\text { 脆化点 } \\
\left({ }^{\circ} \mathrm{C}\right)\end{array}$ & $\begin{array}{c}\text { ハラッキ } \\
\left({ }^{\circ} \mathrm{C}\right)\end{array}$ & $\begin{array}{l}\text { 他裂の } \\
\text { タイブ }\end{array}$ \\
\hline $6 / 23$ & $\begin{array}{l}\text { 前 } \\
\text { 後 }\end{array}$ & $\begin{array}{l}-15.0 \\
-11.5\end{array}$ & $\begin{array}{l}-13 \sim-16 \\
-10 \sim-14\end{array}$ & $\begin{array}{l}-25 \\
-25\end{array}$ & $\begin{array}{l}-25 \cdots-26 \\
-25 \cdots-26\end{array}$ & $\begin{array}{l}1 \\
1\end{array}$ \\
\hline $6 / 26$ & $\begin{array}{l}\text { 前 } \\
\text { 後 }\end{array}$ & $\begin{array}{l}-14.5 \\
-13.5\end{array}$ & $\begin{array}{l}-13 \sim-16 \\
-12 \sim-16\end{array}$ & $\begin{array}{l}-25 \\
-25\end{array}$ & $\begin{array}{l}-25 \cdot-27 \\
-25 \cdot-26\end{array}$ & III \\
\hline $6 / 29$ & $\begin{array}{l}\text { 前 } \\
\text { 後 }\end{array}$ & $\begin{array}{l}-15.0 \\
-16.0\end{array}$ & $\begin{array}{l}-12 \sim-17 \\
-14 \sim-18\end{array}$ & $\begin{array}{l}-23 \\
-24\end{array}$ & $\begin{array}{l}-23 \cdot-24 \\
-24 \cdot-25\end{array}$ & I \\
\hline $7 / 2$ & $\begin{array}{l}\text { 前 } \\
\text { 後 }\end{array}$ & $\begin{array}{l}-13.5 \\
-15.0\end{array}$ & $\begin{array}{l}-13 \sim-15 \\
-13 \sim-17\end{array}$ & $\begin{array}{l}-23 \\
-23\end{array}$ & $\begin{array}{l}-23 \cdot-24 \\
-23 \cdot-24\end{array}$ & $\begin{array}{l}1 \\
1\end{array}$ \\
\hline $7 / 6$ & $\begin{array}{l}\text { 前 } \\
\text { 後 }\end{array}$ & $\begin{array}{l}-14.8 \\
-14.8\end{array}$ & $\begin{array}{l}-12 \sim-19 \\
-12 \sim-17\end{array}$ & $\begin{array}{l}-23 \\
-24\end{array}$ & $\begin{array}{c}\text { なし } \\
-24 \cdot-25\end{array}$ & $\begin{array}{l}1 \\
1\end{array}$ \\
\hline $7 / 8$ & $\begin{array}{l}\text { 前 } \\
\text { 後 }\end{array}$ & $\begin{array}{l}-14.5 \\
-13.5\end{array}$ & $\begin{array}{l}-13 \sim-16 \\
-12 \sim-15\end{array}$ & $\begin{array}{l}-23 \\
-22\end{array}$ & $\begin{array}{l}\text { なし } \\
\text { なし }\end{array}$ & $\begin{array}{l}\text { I } \\
\text { I }\end{array}$ \\
\hline $7 / 11$ & $\begin{array}{l}\text { 前 } \\
\text { 後 }\end{array}$ & $\begin{array}{l}-13.5 \\
-12.8\end{array}$ & $\begin{array}{l}-12 \sim-14 \\
-12 \sim-17\end{array}$ & $\begin{array}{l}-25 \\
-23\end{array}$ & $\begin{array}{c}\text { なし } \\
-23 \cdot-24\end{array}$ & I \\
\hline $7 / 14$ & $\begin{array}{l}\text { 前 } \\
\text { 後 }\end{array}$ & $\begin{array}{l}-16.0 \\
-13.4\end{array}$ & $\begin{array}{l}-14 \sim-20 \\
-12 \sim-17\end{array}$ & $\begin{array}{l}-23 \\
-22\end{array}$ & $\begin{array}{l}-23 \cdot-24 \\
-22 \cdot-23\end{array}$ & $\begin{array}{l}\text { I } \\
\text { I }\end{array}$ \\
\hline $7 / 17$ & $\begin{array}{l}\text { 前 } \\
\text { 後 }\end{array}$ & $\begin{array}{l}-15.8 \\
-13.3\end{array}$ & $\begin{array}{l}-14 \sim-19 \\
-12 \sim-20\end{array}$ & $\begin{array}{l}-23 \\
-23\end{array}$ & $\begin{array}{c}-23 \cdot-24 \\
\text { なし }\end{array}$ & II \\
\hline $7 / 20$ & $\begin{array}{l}\text { 前 } \\
\text { 後 }\end{array}$ & $\begin{array}{l}-15.6 \\
-14.8\end{array}$ & $\begin{array}{l}-14 \sim-19 \\
-13 \sim-17\end{array}$ & $\begin{array}{l}-25 \\
-24\end{array}$ & $\begin{array}{c}\text { なし } \\
-24 \cdot-26\end{array}$ & $\begin{array}{l}1 \\
I\end{array}$ \\
\hline
\end{tabular}

表一10 製油所別アスファルトでの試験結果

\begin{tabular}{|c|c|c|c|c|c|c|}
\hline$T$ & 薄 & フラース脆 & 七点試柗 & & 脆化点試 & \\
\hline p & 加 & $\begin{array}{c}\text { 脆化点 } \\
\left({ }^{\circ} \mathrm{C}\right)\end{array}$ & $\begin{array}{c}\text { バラッキ } \\
\left({ }^{\circ} \mathrm{C}\right)\end{array}$ & $\begin{array}{l}\text { 脆化点 } \\
\left({ }^{\circ} \mathrm{C}\right)\end{array}$ & $\begin{array}{c}\text { バラッキ } \\
\left({ }^{\circ} \mathrm{C}\right)\end{array}$ & $\begin{array}{l}\text { 色裂の } \\
\text { タイブ }\end{array}$ \\
\hline $\begin{array}{l}\mathrm{E} \\
\mathrm{E}\end{array}$ & $\begin{array}{l}\text { 前 } \\
\text { 後 }\end{array}$ & $\begin{array}{l}-14.8 \\
-13.7\end{array}$ & $\begin{array}{l}-13 \sim-16 \\
-13 \sim-15\end{array}$ & $\begin{array}{l}-25 \\
-24\end{array}$ & $\begin{array}{c}\text { なし } \\
-24 \cdot-25\end{array}$ & I, II \\
\hline $\begin{array}{l}F \\
F\end{array}$ & $\begin{array}{l}\text { 前 } \\
\text { 後 }\end{array}$ & $\begin{array}{l}-15.2 \\
-14.0\end{array}$ & $\begin{array}{l}-14 \sim-16 \\
-12 \sim-16\end{array}$ & $\begin{array}{l}-27 \\
-25\end{array}$ & $\begin{array}{c}\text { なし } \\
-25 \cdots-27\end{array}$ & I, II \\
\hline $\begin{array}{l}\text { G } \\
G\end{array}$ & $\begin{array}{l}\text { 前 } \\
\text { 後 }\end{array}$ & $\begin{array}{l}-13.7 \\
-13.3\end{array}$ & $\begin{array}{l}-13 \sim-15 \\
-13 \sim-15\end{array}$ & $\begin{array}{l}-24 \\
-23\end{array}$ & $\begin{array}{l}\text { なし } \\
\text { なし }\end{array}$ & I, II \\
\hline $\begin{array}{l}\mathrm{H} \\
\mathrm{H}\end{array}$ & $\begin{array}{l}\text { 前 } \\
\text { 後 }\end{array}$ & $\begin{array}{l}-13.7 \\
-11.0\end{array}$ & $\begin{array}{l}-13 \sim-14 \\
-10 \sim-12\end{array}$ & $\begin{array}{l}-25 \\
-23\end{array}$ & $\begin{array}{c}\text { なし } \\
-23 \cdots-24\end{array}$ & 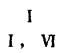 \\
\hline $\begin{array}{l}1 \\
I\end{array}$ & $\begin{array}{l}\text { 前 } \\
\text { 後 }\end{array}$ & $\begin{array}{l}-14.2 \\
-13.8\end{array}$ & $\begin{array}{l}-14 \sim-15 \\
-12 \sim-15\end{array}$ & $\begin{array}{l}-23 \\
-24\end{array}$ & $\begin{array}{l}-23 \cdot-25 \\
-24 \cdot-26\end{array}$ & $\begin{array}{c}\mathrm{I} \\
\mathrm{I}, \mathrm{VI}\end{array}$ \\
\hline J & $\begin{array}{l}\text { 前 } \\
\text { 後 }\end{array}$ & $\begin{array}{l}-14.7 \\
-14.5\end{array}$ & $\begin{array}{l}-13 \sim-17 \\
-13 \sim-15\end{array}$ & $\begin{array}{l}-26 \\
-25\end{array}$ & $\begin{array}{c}\text { なし } \\
-25 ・-27\end{array}$ & I \\
\hline $\begin{array}{l}\mathrm{K} \\
\mathrm{K}\end{array}$ & $\begin{array}{l}\text { 前 } \\
\text { 後 }\end{array}$ & $\begin{array}{l}-15.0 \\
-14.5\end{array}$ & $\begin{array}{l}-14 \sim-16 \\
-14 \sim-15\end{array}$ & $\begin{array}{l}-25 \\
-23\end{array}$ & $\begin{array}{l}-25 \cdot-26 \\
-23 \cdot-24\end{array}$ & 1 \\
\hline $\begin{array}{l}\mathrm{L} \\
\mathrm{L}\end{array}$ & $\begin{array}{l}\text { 命J } \\
\text { 後 }\end{array}$ & $\begin{array}{l}-14.8 \\
-13.6\end{array}$ & $\begin{array}{l}-11 \sim \\
-11 \sim-15\end{array}$ & $\begin{array}{ll}-2 & 5 \\
-2 & 1\end{array}$ & $\begin{array}{c}-25 \cdot-26 \\
\text { なし }\end{array}$ & $\begin{array}{l}1 \\
1\end{array}$ \\
\hline $\begin{array}{l}M \\
M\end{array}$ & $\begin{array}{l}\text { 前 } \\
\text { 後 }\end{array}$ & $\begin{array}{l}-17.5 \\
-13.7\end{array}$ & $\begin{array}{l}-16 \sim-19 \\
-13 \sim-20\end{array}$ & $\begin{array}{l}-23 \\
-22\end{array}$ & $\begin{array}{c}-23 \cdot-25 \\
\text { なし }\end{array}$ & 1 \\
\hline $\begin{array}{l}\mathrm{N} \\
\mathrm{N}\end{array}$ & $\begin{array}{l}\text { 前 } \\
\text { 後 }\end{array}$ & $\begin{array}{r}-12.8 \\
-9.7\end{array}$ & $\begin{array}{r}-12 \sim-14 \\
-9 \sim-11\end{array}$ & $\begin{array}{l}-24 \\
-20\end{array}$ & $\begin{array}{c}\text { なし } \\
-20 \cdots-21\end{array}$ & $\begin{array}{l}1 \\
1\end{array}$ \\
\hline $\begin{array}{l}0 \\
0\end{array}$ & $\begin{array}{l}\text { 前 } \\
\text { 後 }\end{array}$ & $\begin{array}{l}-14.0 \\
-11.2\end{array}$ & $\begin{array}{l}\text { なし } \\
-10 \sim-12\end{array}$ & $\begin{array}{l}-23 \\
-22\end{array}$ & $\begin{array}{l}-23 \cdot-25 \\
-22 \cdot-23\end{array}$ & $\begin{array}{l}1 \\
1\end{array}$ \\
\hline
\end{tabular}




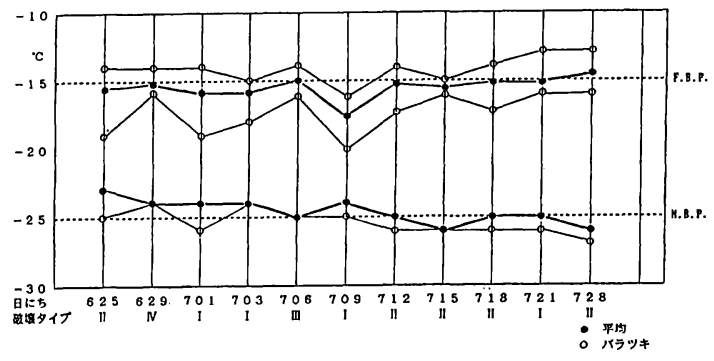

図一2 Type B のアスファルトでの脆化点試験結果 (薄膜加熱前)（プラント 1 )

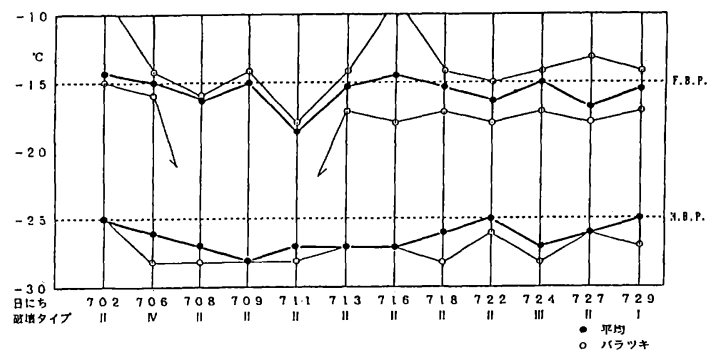

図一3 Type C のアスファルトでの脆化点試験結果 (薄膜加熱前)（プラント 2 )

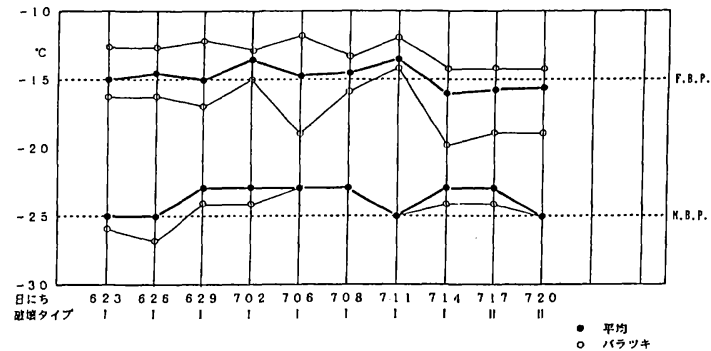

図一4 Type Dのアスファルトでの脆化点試験結果 (薄膜加熱前)（プラント 3 )

同じ針入度級のアスファルトでの日変動は表一6，7， 8 に示したほか, フラース脆化点試験結果の平均値と森

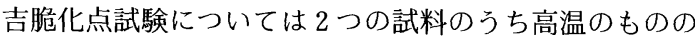
亀裂の生じた温度の変動を図一2，3，4 に示した。これ らをみると, アスファルトは $2 \sim 3^{\circ} \mathrm{C}$ の範囲で変化のあ ることが森吉脆化点結果から明瞭にわかる.これはアス ファルトの性質が製造または輸送の段階で異なったり， あるいは変化したアスファルトがプラントに供給された ためと考えられる．脆化点が混合物の熱応力破壊温度之 深くかかわりをもつので17)，同じ針入度級のアスファル トでも, 混合物の熱応力破壊温度は異なることを示して いる.このことは現状のように外気温を考慮して舗装に 使用するアスファルトを決定する場合，針入度，軟化点 のみの規格では問題があることを提起していると思われ

\section{表一11 ガラス転移点と森吉脆化点試験結果}

\begin{tabular}{|l|l|l|}
\hline $\begin{array}{c}\text { アスファ } \\
\text { ルト }\end{array}$ & $\begin{array}{r}\text { ガラス枟移点 } \\
\left({ }^{\circ} \mathrm{C}\right)\end{array}$ & $\begin{array}{c}\text { 森脱化点 } \\
\left({ }^{\circ} \mathrm{C}\right)\end{array}$ \\
\hline $\mathrm{D}-6 / 23$ & $-34,-37$ & -25 \\
$\mathrm{D}-7 / 6$ & $-32,-36$ & -23 \\
$\mathrm{D}-7 / 20$ & $-32,-35$ & -25 \\
$\mathrm{C}-7 / 2$ & $-35,-37$ & -25 \\
$\mathrm{C}-7 / 9$ & $-38,-39$ & -28 \\
$\mathrm{C}-7 / 29$ & $-31,-35$ & -25 \\
$\mathrm{~B}-7 / 3$ & $-33,-34$ & -24 \\
$\mathrm{~B}-7 / 6$ & $-32,-34$ & -25 \\
$\mathrm{~B}-7 / 15$ & $-30,-33$ & -26 \\
\hline
\end{tabular}

る.

\section{（6）ガラス転移点と森吉脆化点試験結果の比較}

表一11 はガラス転移点測定結果と森吉脆化点試験結 果を示す。これをみると明らかなように両者の温度がほ ぼ対応していることがわかる.すなわち森吉脆化点にお ける亀裂の発生はアスファルトの物理性状の温度に応じ た変化に対応していると推察されるので, 十分なデー夕 の蓄積があれば，ガラス転移点は森吉脆化点と対応関係 にあるように思われる。

\section{（7）亀裂の形状とアスファルトの性質}

アスファルトの種類と亀裂のタイプとのかかわりあい を調べると以下のようなことがいえる．まず，ストレー トアスファルトではタイプIかまたはタイプ亀裂に 属するものが大半を占める，しかし，例外としてたとえ ばタイプII やタイプIVの亀裂に属するものもある．これ についてはストレートアスファルトと称されているもの の, 性質および組成の違いがあるためアスファルトの質 が不均一になったと考えられる。また, 触媒アスファル 卜などでは夕イプVの亀裂に属するものが多い。このう ち，タイプIは亀裂が瞬間的に端から端まで入った場合 と一般には考えられるが，場合によってはタイプIおよ びタイプIVのものが伸長したものも含まれていると考え られる. タイプIIIはタイプIで生じた亀裂がさらされた 温度が低温であったためさらに多数の亀裂が連鎖的に 入った場合とも考えることができる．また，タイプVに 属するものは孟の端部での付着に問題があるようで, 脆 化点は比較的低いものが多かった。

3 社のメーカーの Type B D $\mathrm{D}$ についての薄膜加熱後 も含めた亀裂の形状を調べ，以上に述べた 6 つのタイプ に分類した結果は表一7，8，9に示す。これによるとプ ラント 3 のアスファルトでは夕イプ I が大部分を占める のに対してプラント 2 ではタイプIが大部分であり，ま たプラント 1 のアスファルトではタイプIとタイプII が半々である.このことより, 同じ針入度級でもメーカー によってアスファルトの性質の異なるアスファルトであ ることは明らかである. 特にプラント 1 のアスファルト についてはもしこのように亀裂の種類によってアスファ 


\section{表一12 高速道路使用アスファルトでの試験結果}

\begin{tabular}{|c|c|c|c|c|c|c|}
\hline $\mathrm{T}$ & 蒲 & 万ラース睡 & 化点試騟 & & 吉脆化点嘼 & \\
\hline $\begin{array}{l}\mathrm{p} \\
\mathrm{e}\end{array}$ & $\begin{array}{l}\text { net } \\
\text { 加 } \\
\text { 熱 }\end{array}$ & $\begin{array}{l}\text { 胞化点 } \\
\left({ }^{\circ} \mathrm{C}\right)\end{array}$ & $\begin{array}{c}\text { バラツキ } \\
(\text { ( })\end{array}$ & $\begin{array}{l}\text { 脆化点 } \\
\left({ }^{\circ} \mathrm{C}\right)\end{array}$ & $\begin{array}{c}\text { バラッキ } \\
\left({ }^{\circ} \mathrm{C}\right)\end{array}$ & $\begin{array}{l}\text { 我裂の } \\
\text { タイフ }\end{array}$ \\
\hline $\mathrm{P}$ & 前 & -13.8 & $\sim-16$ & -22 & & I \\
\hline Q & 前 & -12.2 & $-11 \sim-13$ & -22 & $-22 \cdot-23$ & I \\
\hline
\end{tabular}

ルトが明確に分類されるのであれば品質の異なるアス ファルトがプラントにおいて混合された結果であるとも 考えることができる. 一方, 薄膜加熱後での亀裂の分類 結果をみると，特にプラント 2 のアスファルトでは多数 がタイプIIからタイプIへと転移しているのがわかる.

これは薄膜加熱の結果このアスファルトが均質なものに なったことによるものと思われる。一方，プラント 3 の アスファルトではほぼ夕イプIであるとみなされ，プラ ント 1 のアスファルトでは加熱前の分類結果とあまり変 わらないようであり，これらの場合については亀裂の形 状から薄膜加熱によってアスファルトの性質の変化はな かったということができる.なお，これらの 3 社のメ一 カーから採取したアスファルトの物理試験の結果はこの 期間中全く同一のものであった。

また表一10は各製油所から採取した Type E〜Oのア スファルトの結果を示す．これによると製油所での生産 段階においてはほとんぼが夕イプI となっている。これ はタイプIのような亀裂がみられた場合，製造以後に性 状の異なる他のアスファルトと混合されず均質なアス ファルトであるという可能性が高いことを示唆している ように思われる.

以上より亀裂の形状によってアスファルトの不均一性 を推定することはある程度可能であることがわかる.

\section{（8）高速自動車道使用アスファルトでの性状}

表一12 は高速自動車道の相隣る工事区間で使用した アスファルトのフラース脆化点, 森吉脆化点と亀裂の形 状を示す。これより両者で使用したアスファルトはメー カーが異なるとされているが，脆化点や破壊形状から両 者ほぼ同一のアスファルトであるように思われる.

\section{（9）森吉脆化点，フラース脆化点と混合物の熱応力} 破壊温度との関係

図一 5 はフラース脆化点, 森吉脆化点と混合物の熱応 力試験による破壊温度との相関を示す。これによると低 針入度から高針入度の広範囲な針入度級のアスファルト に対して両脆化点と混合物の熱応力破壊温度の間には一 定の関係がある.ここではアスファルト混合物の治具の 接着方法が袋状または突合せ状の両者とも熱応力破壊温 度はほぼ同一のように思われる.図に記した直線により， 脆化点試験の結果から実際の舗装体における破壊温度の 推定が可能であると考えられる.

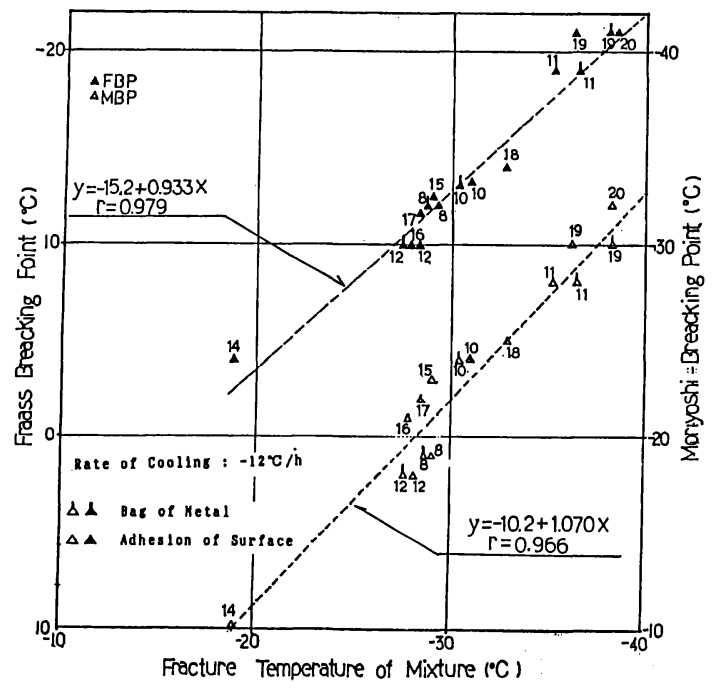

図一5 同一の粒度およびアスファルト量, 異種のアスファルト での熱応力破壊温度とフラース脆化点, 森吉脆化点との 関係

\section{5. 結 論}

以上述べたことを要約すると以下のとおりである.

（1）森吉脆化点はアスファルトの厚さおよび皿の形 状に依存するが，同一の形状，同一の材質の条件で実験 を行うとフラース脆化点よりも再現性に優れている.

(2））森吉脆化点試験におけるアスファルトの亀裂形 状はアスファルトの品質と関係があるように思われる.

（3）アスファルトの低温性状はメーカーや製油所, および日ごとに異なる.

（4）森吉脆化点はガラス転移点と対応関係にあるよ うに思われる。

（5）森吉脆化点は室内作成のアスファルト混合物の 熱応力破壊温度と密接な関係にあることから，この温度 はアスファルト舗装の低温亀裂現象の 1 つの指標になる と思われる.

本研究を遂行するにあたり, 本学電気工学科の深井一 郎教授にご助言を頂いた．また試料採取に際して建設省 土木研究所, 日本道路公団札幌建設局および北海道庁の 皆様に大変お世話になった．論文の作成にあたっては， 大田黒直文，高橋正人両君にご協力頂いた．関係者の皆 様にここに感謝の意を表する.

なお，森吉脆化点試験は日本道路公団札幌建設局の試 験舗装の特記示椂書に盛り込まれ，現在アスファルトの 品質管理試験として採用されている。この試験は寒冷地 のアスファルトの品質管理試験というだけでなく，アス ファルトの高温領域の軟化点試験と対応した低温領域の 精度の良い試験の一種といえる。したがって温暖地や熱 
帯においてもこの試験法は広範囲な温度領域のアスファ ルトの品質を規定するために必要となると思われる.

\section{参 考 文 献}

1) Rader, L.F. : Investigations of the Physical Properties of Asphaltic Mixtures at Low Temperatures, Proc. of ASTM, Vol. 35, PartII, pp. 559 580, 1935.

2) Monismith, C. L. : Non-Traffic Load Associated Cracking of Asphalt Pavements, PAAPT, Vol.35, pp. 239 357, 1966.

3) Canadian Good Roads Association Ad Hoc Comittee on Low Temperature Behavior of Flexible Pavements, Proc. of Canadian Good Roads Association, pp.69 $122,1970$.

4) Haas, R. C. G. : A Method for Designing Asphalt Pavements to Minimize Low-Temperature Shrinkage Cracking, The Asphalt Institute, Research Report 73-1 (RR-73-1), pp. 1 91, January 1973.

5) Sugawara, T. et al. : Low Temperature Cracking of Asphalt Pavements, Paving in Cold Area, Mini-Workshop, Canada/Japan Science and Technology Consultations, 1982.

6) Shields, B. P., Anderson, K. O. and Dacyszyn, J. M. : An Investigation of Low Temperature Transverse Cracking of Flexible Pavements, Proc. of Canadian Good Roads Association, pp. 273 308, 1969.

7）渋沢芳雄, ほか：道路舗装用アスファルトのフラース脆
化点について, アスファルト, Vol.8, No.43, pp.6 11, 1965年 4 月.

8）森吉昭博・高橋 将・張 肖寧：低温領域におけるアス ファルトの亀裂試験法, 石油学会誌, 第 30 巻, 第 4 号, pp. 273 275, 1987 年 7 月.

9）森吉昭博・新田 登：脆性領域におけるアスファルト混 合物の破壊に関する研究，土木学会論文集，第 390 号／ $\mathrm{V}-8, \mathrm{pp} .219 \sim 223,1988$ 年 2 月.

10）森吉昭博：アスファルト混合物の熱応力破壊, 石油学会 誌, 第 31 巻, 第 2 号, pp. 172 175, 1988 年 3 月.

11）森吉昭博, ほか：アスファルト混合物の熱応力破壊とア スファルトの性状との関係, 土木学会北海道支部論文報 告集, Vol. 44, pp. 605 608, 1983 年 2 月.

12) 8) ibit

13）森吉昭博, ほか：森吉脆化点試験の応力解析, 土木学会 北海道支部論文集, Vol. 44, pp. 601 604，1983 年 2 月.

14) 10) ibit

15）森吉昭博・水沢 隆：アスファルト混合物の熱応力試験 に関する基礎的研究，土木学会論文集，第 384 号 /V -7, pp. 137〜141, 1987 年 8 月.

16) 13) ibit

17) 11) ibit

18）森吉昭博：アスファルト及びアスファルト混合物の低温 脆性に関する研究, 土木学会第 43 回年次学術講演会講演 概要集, pp. 2〜3, 1988 年 10 月.

(1988.10.26 • 受付) 